\title{
Analisis Literasi Teknologi Guru Bimbingan Dan Konseling Se-Dki Jakarta Menghadapi Era Industri 4.0
}

\author{
${ }^{1}$ Dede Hermawan, ${ }^{2}$ Syifa Aisyah ${ }^{3}$ Khoirunnissa \\ ${ }^{1}$ Bimbingan dan Konseling, Universitas Muhammadiyah Prof. DR. HAMKA, \\ ${ }^{2}$ Bimbingan dan Konseling, Universitas Muhammadiyah Prof. DR. HAMKA \\ ${ }^{3}$ Bimbingan dan Konseling, Universitas Muhammadiyah Prof. DR. HAMKA \\ Correspondence:email.'1dedehf97@gmail.com
}

\begin{abstract}
Abstrak: Literasi teknologi merupakan kemampuan untuk mengoprasikan, mengelola, menilai dan memahami teknologi. Penelitian ini bertujuan untuk mengetahui gambaran empirik mengenai tingkat literasi teknologi yang dimiliki guru Bimbingan dan Konseling SMP/MTs di DKI Jakarta. Penelitian ini menggunaan pendekatan kuantitatif dengan metode penelitian deskriptif. Pengumpulan data dilakukan menggunakan instrumen literasi teknologi yang berbentuk self assessment dengan metode survei mengambil sampel sebanyak 157 guru Bimbingan dan Konseling SMP/MTs se-DKI Jakarta. Hasil uji validitas didapat sebanyak 36 butir pernyataan. Uji reabilitas yang didapat yaitu 0,934 yang berarti instrumen memiliki reliabilitas sangat tinggi sehingga instrumen dapat dipercaya keajegannya. Hasil penelitian terkait tingkat literasi teknologi ini menunjukan bahwa $61,14 \%$ guru BK ada pada kategori sangat tinggi dan tinggi, 35,03\% pada kategori cukup serta $3,82 \%$ ada pada kategori rendah dan sangat rendah.
\end{abstract}

Kata kunci: Literasi Teknologi, Guru Bimbingan dan Konseling

\begin{abstract}
Technology literacy is the capacity to operate, manage, assess and realize the technology is. This study aims to determine an empirical description of the level of technological literacy owned by counselor/counseling teacher in Jakarta. This research uses a quantitative approach with descriptive research methods. The data collection was worked out using by technology literacy instruments by taking a sample from 157 junior high school with counseling teachers around DKI Jakarta. The results of the research related to the level of technological literacy showed that $61.14 \%$ of counseling teachers were in the top categories, which iz $35.03 \%$ in the sufficient category and $3.82 \%$ in the low and very low categories.
\end{abstract}

Keyword: Technology Literacy, School Counselor

Ini adalah artikel dengan akses terbuka dibawah licenci $C C B Y-N C-4.0$ (c) (i) (9) (https://creativecommons.org/licenses/by-nc/4.0/)

\section{PENDAHULUAN}

Era revolusi industri 4.0, merupakan real change dari perubahan yang ada. Fase ini ditandai dengan kemajuan dan gelombang perubahan dinamis atau dikenal dengan fenomena disruptive innovation (Ristekdikti, 2018) termasuk penggunaan teknologi dalam dunia pendidikan.
Disruptive innovation mengakibatkan ketidakmampuan konselor sekolah terlepas dari teknologi. Cabaniss menyimpulkan dalam penelitiannya bahwa konselor sudah tidak dapat melakukan pekerjaan tanpa bantuan komputer (Springer, 2005). Namun, fakta yang terjadi di sekolah menunjukan banyak konselor sekolah gagap tentang teknologi (Triyanto, 2010). Hal tersebut bertentangan dengan tantangan bagi peserta didik sebagai generasi digital native yang 
mengharapkan penggunaan teknologi dalam pembelajaran. Maka pendidik harus memanfaatkan teknologi. Pendidik harus dapat memanfaatkan teknologi dalam proses-proses administrative sehingga memungkinkan memiliki waktu luang untuk pengembangan diri. Kemudian laporan berbasis teknologi, sehingga memudahkan dalam mengidentifikasi, mengenali dan memenuhi kebutuhan pembelajaran dan pemberian pelayanan kepada peserta didik.

Arsad, Osman, \& Soh dalam penelitiannya menunjukan bahwa hasil penelitian ini menunjukan terdapat 4 komponen keterampilan abad 21 dari en Gauge 21st century skills, yakni: (1) digital-age literacy, (2) inventive thinking, (3) effective ommunication, dan (4) high productivity, serta satu komponen lainnya yakni, spiritual values. (Junanto, et al., 2016). Maka, hal pertama yaitu digital-age literacy menjadi komponen utama, mengindikasikan keharusan pendidik termasuk guru Bimbingan dan Konseling untuk meningkatkan diri pada literasi teknologi.

Untuk merespon tersebut maka terdapat pergeseran literasi lama oleh gerakan literasi baru, menurut Aoun (2017, dalam Yahya, 2018) gerakan literasi yang terfokus pada tiga literasi utama yaitu literasi digital, literasi teknologi dan literasi manusia. Literasi teknologi bertujuan memberikan pemahaman pada cara kerja mesin dan aplikasi teknologi.

Literasi teknologi didefinisikan sebagai kemampuan untuk menggunakan, mengelola, menilai dan memahami teknologi (Rose, 2017). Literasi teknologi terdiri dari tiga komponen utama yaitu pengetahuan, kemampuan dan berpikir kritis, serta pembuatan keputusan. (National Academy of Engineering and National Research Council of The National Academis, 2016) Individu pada tahap independent computer literacy mampu (1) menghubungkan penggunaan komputer dan perangkat lunak dengan aktivitas internet (2) menggunakan komputer secara independen, (3) menyelesaikan dan menghindari masalah, (4) beradaptasi dengan situasi baru (Robinson, 2008).

Terdapat empat elemen program Bimbingan dan Konseling yang harus dijalankan secara efektif dan efisien yaitu landasan (foundation), sistem penyampaian (delivery system), sistem manajemen (management system) dan akuntabilitas (accountability) (Yusuf, 2017). Keempat elemen penting ini memberikan gambaran yang luas akan pentingnya peningkatan literasi teknologi bagi seorang guru Bimbingan dan Konseling. khususnya guru bimbingan dan konseling (BK) dituntut untuk membuat program yang sesuai dengan kebutuhan peserta didik. Hal itu dilakukan menggunakan berbagai asesmen yang pengolahan dan analisis berbasis PC (personal computer). Lebih lanjut dalam pembuatan program BK guru Bimbingan dan Konseling dituntut untuk membuatnya dengan efektif dan efisien dan sesuia dengan kebutuhan peserta didik..

American School Counselor Association (ASCA) (Bhakti, 2017) merekomendasikan konselor sekolah memberikan alokasi waktu layanan minimal $80 \%$ atau lebih pada komponen direktif pada peserta didik. Sedangkan sisanya untuk aktivitas manajemen program dan dukungan sistem (asesmen tes dan asesmen non tes). Selain itu, guru Bimbingan dan Konseling juga mengalokasikan waktu dari $20 \%$ tersebut terhadap akuntabilitas (Results Reports, evaluasi). Bahkan dalam Permendikbud No. 111 Tahun 2014 Tentang Bimbingan Dan Konseling pada Pendidikan Dasar dan Pendidikan Menengah hanya mengalokasikan waktu maksimal $10-15 \%$ selain layanan direktif. Oleh karena itu, dengan alokasi waktu yang begitu minimal, guru BK tidak bisa bekerja maksimal jika tidak mampu menggunakan teknologi.

Konselor memiliki standar literasi teknologi oleh Association for Counselor Education and Supervision (ACES). ACES membuat 12 poin kompetensi terhadap teknologi yang perlu dikembangkan oleh para konselor (Intan, et al., 2017) yaitu sebagai berikut: (1) Mampu menggunakan piranti lunak untuk mengembangkan halaman web, presentasi kelompok, surat dan laporan-laporan, (2) mampu menggunakan perlengkapan audiovisual, seperti rekaman video, rekaman suara, perlengkapan proyektor dan perlengkapan konferensi video, (3) mampu menggunakan statistika berbasis komputer, (4) mampu menggunakan aplikasi berbasis komputer untuk tes-tes/asesmen, melakukan diagnosis, program keputusan karir bagi konseli atau peserta didik, (5) Mampu menggunakan email, (6) mampu membantu konseli menemukan berbagai informasi terkait dengan keperluan konseling melalui internet, seperti informasi karir, kesempatan kerja, kesempatan pelatihan-pelatihan pengembangan diri, bantuan keuangan dan atau beasiswa, prosedur penyembuhan hingga informasi mengenai hal-hal pribadi, sosial, dan belajar (7) mengikuti berbagai kegiatan pengembangan 
konseling secara online, (8) mampu menggunakan perlengkapan penyimpanan data melalui CD-ROM, (9) mengetahui dan memahami aspek hukum dan etika terkait dengan layanan konseling melalui internet, (10) mengetahui dan memahami kelebihan maupun kekurangan dari konseling melalui internet, (11) mampu menggunakan internet untuk mencari berbagai kesempatan dalam rangka meneruskan pendidikan untuk konseling, dan (12) mampu mengevaluasi kualitas informasi di internet.

\section{METODE}

Penelitian ini menggunaan pendekatan kuantitatif dengan metode penelitian deskriptif. Jenis yang digunakan dalam penelitian deskriptif ini adalah survei. Penelitian dilaksanakan di Provinsi DKI Jakarta terdiri dari lima wilayah kota yaitu Jakarta Pusat, Jakarta Timur, Jakarta Selatan, Jakarta Barat dan Jakarta Utara, dengan jumlah keseluruhan guru bimbingan dan konseling SMP/Sederajat (populasi) berjumlah
1223 guru. Penentuan subjek dalam penelitian ini menggunakan metode Random Sampling yang artinya setiap anggota populasi memiliki kesempatan yang sama untuk dijadikan sampel dalam penelitian ini. Terkait jumlah sampel yang akan diambil dalam penelitian ini didasarkan pada pendapat Roscoe (1975) menyatakan Sample sizes larges than 30 and less than 500 are appropriate most research (Ukuran sampel lebih dari 30 dan kurang dari 500 adalah tepat untuk kebanyakan penelitian) (dalam Sekaran, 2002). Responden yang terlibat dalam studi ini berjumlah 157 guru bimbingan dan konseling seDKI Jakarta.

Pengambilan data ini menggunakan instrument literasi teknologi konselor dalam bentuk self assessment yang diberikan melalui google formulir. Skala yang digunakan yaitu menggunakan skala likert.

Bobot dari tiap-tiap pilihan jawaban dipaparkan seperti tabel 1 .

Tabel 1 Bobot Tiap-Tiap Pilihan Jawaban

\begin{tabular}{lll}
\hline Pilihan Jawaban & Favorabel & Unfavorabel \\
\hline Sangat Setuju (SS) & 4 & 0 \\
Setuju (ST) & 3 & 1 \\
Ragu-Ragu (RG) & 2 & 2 \\
Kurang Setuju (KS) & 1 & 3 \\
Tidak Setuju (TS) & 0 & 4 \\
\hline
\end{tabular}

Penyajian data dari hasil penelitian ini akan dikategorisasikan dalam lima kategorisasi. Berikut kriteria perolehan skor literasi teknologi secara lengkap dalam tabel di bawah ini.

Tabel 2 Kategorisasi Literasi Teknologi

\begin{tabular}{lll}
\hline Perolehan Skor & Konversi Skor & Keterangan \\
\hline $0 \%-20 \%$ & $0-28$ & Sangat Rendah \\
$20,1 \%-40 \%$ & $29-57$ & Rendah \\
$40,1 \%-60,99 \%$ & $58-87$ & Cukup \\
$61 \%-80,99 \%$ & $88-116$ & Tinggi \\
$81 \%-100 \%$ & $117-144$ & Sangat Tinggi \\
\hline
\end{tabular}

\section{HASIL DAN PEMBAHASAN}

Hasil yang diperoleh berdasarkan isian instrument yang berisi 36 butir pernyataan tentang literasi teknologi diperoleh data, bahwa 28 guru BK yang termasuk kategori sangat tinggi dalam literasi teknologi. Selanjutnya pada kategori tinggi dan cukup terdapat 68 guru BK dan 55 guru BK. Sedangkan 5 guru BK berada pada kategori rendah serta 1 guru BK pada kategori sangat rendah. Hasil ini artinya menunjukan bahwa lebih dari separuh yaitu sebesar $61,14 \%$ pada kategori tinggi dan sangat tinggi. Hasil secara rinci disajikan pada tabel 3. 
Tabel 3 Data Tingkat Literasi Teknologi Guru BK SMP/MTs di DKI Jakarta

\begin{tabular}{lllll}
\hline Perolehan Skor & Konversi Skor & Frekuensi & Persentase & Keterangan \\
\hline $0 \%-20 \%$ & $0-28$ & 1 & $0,64 \%$ & Sangat Rendah \\
$20,1 \%-40 \%$ & $29-57$ & 5 & $3,18 \%$ & Rendah \\
$40,1 \%-60,99 \%$ & $58-87$ & 55 & $35,03 \%$ & Cukup \\
$61 \%-80,99 \%$ & $88-116$ & 68 & $43,31 \%$ & Tinggi \\
$81 \%-100 \%$ & $117-144$ & 28 & $17,83 \%$ & Sangat Tinggi \\
\hline
\end{tabular}

Adapun tingkat usia berkorelasi dengan tingkat literasi teknologi mencapai signifikansi sebesar 0,00 ; seperti tertera dalam tabel 4 . Nilai tersebut bermakna terdapat hubungan yang sangat tinggi antara usia responden dengan tingkat literasi teknologi. Dimana kelompok usia yang semakin muda menunjukan tingkat literasi yang semakin tinggi dibandingkan kelompok usia. Data selengkapnya tersaji dalam tabel 5.

Tabel 4 Korelasi Usia dengan Tingkat Literasi Teknologi

\begin{tabular}{llll}
\hline & & Usia & $\begin{array}{l}\text { Skor_Literasi } \\
\text { Teknologi }\end{array}$ \\
\hline Usia & Pearson correlation & 1 & $-.366^{* *}$ \\
& Sig. (2. Tailed) & & .000 \\
Skor_Literasi & $\mathrm{N}$ & 157 & 157 \\
Teknologi & Pearson correlation & $-.366^{* *}$ & 1 \\
$* *$ Correlation is significant at the 0.01 level (2-tailed). & Sig. (2. Tailed) & .000 & 157 \\
\hline
\end{tabular}

Tabel 5 Sebaran Nilai Literasi Teknologi berdasarkan kelompok usia

\begin{tabular}{llll}
\hline Usia (Tahun) & Mean & N & Std. Deviation \\
\hline $20-30$ & 110,44 & 27 & 18,882 \\
$30-40$ & 103,97 & 30 & 22,807 \\
$40-50$ & 91,19 & 32 & 23,360 \\
$50-60$ & 88,65 & 68 & 21,630 \\
Total & 95,84 & 157 & 23,275 \\
\hline
\end{tabular}

Berdasarkan wilayah kerja responden serta lulusan pendidikan profesi konseling (PPK) tidak memiliki hubungan yang signifikan terhadap tingkat literasi teknologi guru BK.

Berdasarkan hasil studi di atas menunjukkan bahwa tingkat literasi teknologi guru BK dapat dikatakan baik. Hal tersebut dilihat lebih dari separuh guru BK yaitu sebesar $61,14 \%$ berada pada kategori tinggi dan sangat tinggi yang mengindikasikan bahwa guru BK memiliki literasi teknologi yang kompeten. Penelitian ini mengkonfirmasi studi sebelumnya yaitu mengenai kompetensi guru BK terhadap teknologi yang mengatakan bahwa sebesar
$62,2 \%$ guru BK berada pada tingkat kompetensi teknologi dengan kategori sedang. (Zarirah, Intan, \& Herdi, 2017) ini menunjukkan bahwa kompetensi teknologi yang baik dapat mendukung meningkatnya literasi teknologi guru Bimbingan dan Konseling.

Selain hal itu, hasil studi ini menggambarkan bahwa literasi teknologi guru BK di DKI Jakarta didukung dengan besarnya pengguna internet di pulau jawa sebesar 58,08\% dibandingkan diluar pulau jawa. Besarnya pengguna internet di pulau jawa, DKI Jakarta sebagai salah satu pusat kota yang ada di pulau jawa memudahkan guru BK untuk mengakses 
berbagai informasi melalui internet dan menyambungkannya dengan teknologi yang dimiliki. Maka dimungkinkan tingginya literasi teknologi guru BK di DKI Jakarta ini karena mudahnya akses internet.

Guru bimbingan dan konseling di DKI Jakarta memiliki berbagai agenda yang diadakan untuk meningkatkan kompetensi guru BK. salah satu kegaiatan tersebut yang dilakukan yaitu pengabdian masyarakat yang salah satu tujuannya untuk meningkatkan diri terhadap kompetensi teknologi yang dapat berdampak pada peningakatan literasi teknologi. Salah satunya unsur yang dilakukan dalam pengabdian tersebut yaitu pelatihan pengolahan asesmen yang berbasis teknologi dengan pengolahan data menggunakan Microsoft Word dan Microsoft Excel, pengembangan website, serta penggunaan google form (Cahyawulan, Badrujaman, Fitriyani, Mamesah, \& Konseling, 2019). Tentunya upaya peningkatan kompetensi guru BK terkhusus dalam bidang teknologi dan informasi ini berdampak memungkinkan memiliki dampak positif terhadap tingginya tingkat literasi teknologi guru bimbingan dan konseling.

Hal yang menarik dari data hasil studi ini yaitu adanya korelasi yang signifikan antara usia responden dengan nilai literasi teknologi guru BK. Semakin muda kelompok usia responden semakin baik pula tingkat literasi teknologi dibandingkan dengan kelompok usia yang lebih tinggi, sehingga kelompok usia 20-30 tahun menjadi kelompok usia yang paling tinggi tingkat literasi teknologinya dibandingkan kelompok usia lainnya. Hal ini sejalan dengan konsep teori perbedaan generasi (generational differences) dimana empat kelompok usia dalam penelitian ini terbagi kedalam tiga generasi yang berbeda yaitu generasi $\mathrm{X}$, generasi $\mathrm{Y}$, dan generasi $\mathrm{Z}$.

Penelitian yang dilakukan oleh Bencsik dan Machova (2016, dalam Putra, 2016) menunjukan bahwa ada perbedaan karakteristik yang signifikan antara generasi $\mathrm{Z}$ dengan generasi lainnya yaitu faktor utama yang membedakan keduanya adalah penguasaan informasi dan teknologi (IT). Generasi Z yang merupakan kelompok usia kelahiran 1995-2010 berkarakter "Intuitive" dalam penguasaan IT sehingga disebut generasi internet, karena pada dasarnya generasi ini sejak kecil sudah mengenal teknologi secara akrab dan mampu melakukan pekerjaan menggunakan teknologi dalam sekali waktu "multi tasking" (Putra, 2016). Generasi Z menjadi sangat terbiasa dan terampil dan kemampuan beradaptasi yang baik terhadap perubahan teknologi yang cepat karena sudah terbiasa untuk menggunakan berbagai teknologi sejak dini. Selanjutnya generasi Y kelompok usia kelahiran 1980-1995 dengan karakter penguasaan IT "Part of its every day life" terkenal dengan sebutan generasi milineal dimana generasi ini merupakan generasi yang aktif menggunakan teknologi dalam kehidupan sehari-hari memiliki kemiripan dengan generasi $\mathrm{Z}$ yang membedakan keduanya adalah bahwa generasi $\mathrm{Z}$ lebih mampu mengoperasikan berbagai kegiatan dalam satu waktu.. Sedangkan generasi X kelompok usia kelahiran 1960-1980 berkarakter "Uses with confidence" artinya dimana generasi ini tumbuh dan berkembang ketika lahirnya teknologi baru lahir dan berkembang seperti PC (personal computer) sehingga memiliki kecenderungan yang perlu penyesuaian lebih terhadap teknologi yang berkembang saat ini.

Apabila diperhatikan hasil peneltian Bencsik dan Machova dan kaitannya antara kelompok usia dan tingkat literasi teknologi pada hasil penelitian ini, responden yang kelompok usia lebih muda antara 20-30 tahun merupakan generasi $\mathrm{Z}$ dan sebagaian ada pada generasi $\mathrm{Y}$ akhir menggambarkan tingkat literasi yang tinggi, sedangkan kelompok usia di atasnya yaitu 30-40 ada pada generasi $Y$ lebih rendah dibandingkan generasi Z. Kelompok usia 40-50 Tahun dan 50-60 Tahun berada pada kategori generasi $\mathrm{X}$ dibandingkan dengan dua generasi sebelumnya memiliki tingkat literasi yang lebih rendah. Sehingga hasil penelitian ini menunjukan perbedaan karakteristik antar generasi sangat mempengaruhi seseorang terhadap tingkat literasi teknologi tersebut. Hal ini dapat dipahami bagaimana kelompok usia 20-30 tahun yang umumnya sejak kecil sudah mengenal teknologi, memugkinkan untuk menguasai dan terbiasa beraktifitas diberbagai pekerjaan yang dilakukan sudah menggunakan teknologi tinggi seperti smartphone dan PC (personal computer). 
Tabel 6 Perbedaan Karakteristik Setiap Generasi dan Tingkat Literasi Teknologi

\begin{tabular}{lllllll}
\hline Generasi & $\begin{array}{l}\text { Rentang } \\
\text { Lahir }\end{array}$ & IT & $\begin{array}{l}\text { Usia } \\
\text { (Tahun) }\end{array}$ & Mean & N & $\begin{array}{l}\text { Std. } \\
\text { Deviation }\end{array}$ \\
\hline Generasi Z & $1995-2010$ & Intuitive & $20-30$ & 110,44 & 27 & 18,882 \\
Generasi Y & $1980-1995$ & Part of its every day life & $30-40$ & 103,97 & 30 & 22,807 \\
Generasi X & $1960-1980$ & Uses with confidence & $40-50$ & 91,19 & 32 & 23,360 \\
& & & $50-60$ & 88,65 & 68 & 21,630 \\
& & Total & 95,84 & 157 & 23,275 \\
\hline
\end{tabular}

Berdasarkan wilayah kerja responden tidak memiliki hubungan yang signifikan dengan tingkat literasi guru bimbingan dan konseling. Hal ini bisa dipahami bahwa dimungkinkan sebaran pendidikan di DKI Jakarta yang cukup merata di lima wilayah kota tersebut yaitu Jakarta Timur, Jakarta Barat, Jakarta Selatan, Jakarta Pusat dan Jakarta Utara. Selain itu, dimungkinkan dikarenakan sebaran guru Bimbingan dan Konseling yang berada di lima wilayah kota tersebut merupakan lulusan jurusan bimbingan dan konseling. Data menunjukan dari 157 guru BK terdapat 85,8\% atau 133 guru Bimbingan dan Konseling merupakan lulusan prodi bimbingan dan konseling dari perguruan Tinggi S1 maupun S2. Sedangkan jumlah guru BK lulusan non bimbingan dan konseling hanya terdapat sejumlah 24 atau $14,2 \%$, sehingga dimungkinkan memiliki kompetensi yang cukup merata sesuai kompetensi lulusan bimbingan dan konseling.

Lulusan pendidikan profesi konseling (PPK) ternyata dalam penelitian ini tidak memiliki hubungan yang signifikan terhadap tingkat literasi teknologi guru Bimbiinga dan Konseling. Padahal semestinya semakin tinggi pendidikan seseorang maka tingkat literasi teknologi dimungkinkan untuk lebih baik. Walaupun bisa dilihat latar belakang serta motivasi untuk mengikuti atau melanjutkan pada pendidikan lanjutan tersebut. Jika dilihat lulusan pendidikan profesi konseling (PPK) itu sendiri cukup besar dari data sampel sebanyak 157 guru BK terdapat sebanyak 63 guru BK atau 40,12\% yang merupakan lulusan PPK sedangkan 94 guru BK atau 59,88\% bukan lulusan pendidikan profesi konseling (PPK).

\section{SIMPULAN DAN SARAN}

Adapun simpulan dari studi ini menunjukkan bahwa $61,14 \%$ guru BK berada pada kategori literasi teknologi yang tinggi dan sangat tinggi, 35,03\% pada kategori cukup serta $3,82 \%$ ada pada kategori rendah dan sangat rendah. Selain itu, studi ini menunjukan bahwa wilayah kerja responden serta lulusan pendidikan profesi konseling (PPK) tidak memiliki hubungan yang signifikan terhadap tingkat literasi teknologi guru BK. Sedangkan, usia memiliki signifikansi yang sangat tinggi terhadap tingkat literasi guru BK. Data menunjukan bahwa kelompok usia 20-30 tahun merupakan kelompok usia dengan literasi teknologi tertinggi. Semakin tinggi kelompok usia maka responden semakin rendah tingkat literasi teknologi dan sebaliknya semakin rendah atau muda usia kelompok responden semakin tinggi skor literasi teknologi guru bimbingan dan konseling. Namun, perlu dilakukan penelitian lanjutan yang lebih spesifik melihat keterkaitan faktor-faktor yang dapat mempengaruhi perkembangan literasi teknologi guru Bimbingan dan Konseling, serta melihat berapa lama pengalaman guru Bimbingan dan Konseling sudah melaksanakan profesinya sebagai guru Bimbingan dan Konseling di sekolah.

\section{DAFTAR RUJUKAN}

Afandi, Junanto, T., \& Afriani, R. (2016). Implementasi Digital-Age Literacy Dalam Pendidikan Abad 21 Di Indonesia. Surakarta: Prosiding Seminar Nasional Pendidikan Sains (SNPS) 2016.

Bhakti, C. P. (2017). Program Bimbingan dan Konseling Komprehensif untuk Mengembangkan Standar Kompetensi Siswa. Jurnal Konseling Andi Matappa, l(1), 131-142.

Cahyawulan, W., Badrujaman, A., Fitriyani, H., Mamesah, M., \& Konseling, B. (2019). Peningkatan Kompetensi Teknologi dan Informasi Guru Bimbingan dan Konseling, l(3), 195-199. 
National Academy of Engineering and National Research Council of The National Academis. (2016). Tech Tally: Approaches to Assessing Technological Literacy. Retrieved Oktober 2018, from http://download.nap.edu/cart/download.cg i?\&record_id=11691\&free $=1$

Putra, Y. S. (2016). Theoritical Review: Teori Perbedaan generasi. Among Makarti, 9(1952), 123-134.

Ristekdikti. (2018). Era Revolusi Industri 4.0, Saatnya Generasi Millennial Menjadi Dosen Masa Depan. Retrieved September 20, 2018, from http://sumberdaya.ristekdikti.go.id/index. php/2018/01/30/era-revolusi-industri-4-0saatnya-generasi-millennial-menjadidosen-masa-depan/

Robinson, H. M. (2008). Emergent computer literacy: A developmental perspective. Routledge. New York. https://doi.org/10.4324/9780203887912

Rose, M. A. (2017). Perceptions of Technological Literacy among Science, Technology, Engineering, and Mathematics. Journal of Technology Education, 19(1), 35-52.

Sekaran, U. (2002). Research Methods for Bussiness: A Skill Building Approach. USA: John Wiley dan Sons, Inc.

Springer, G. J. (2005, May). Dissertation.com. Retrieved September 20, 2018, from http://www.bookpump.com/dps/pdfb/1122934b.pdf
Triyanto, A. (2010). implikasi perkembangan teknologi komuter dan Internet bagi konselor sekolah. Paradigma, V(12), 1528.

Wardani, R. (2018). 21st Century Educator: Menyongsong Transformasi Pendidikan 4.0. Yogyakarta: Disampaikan pada Seminar Nasional DInamika Informatika Senadi UPY 2018. Retrieved from http://senadi.upy.ac.id/wpcontent/uploads/2018/05/Materi-RatnaWardani.pdf

Yahya, M. (2018). Era Industri 4.0: Tantangan dan Peluang Perkembangan Pendidikan Kejuruan Indonesia. Pidato Pengukuhan Penerimaan Jabatan Professor Tetap Dalam Bidang Ilmu Pendidikan Kejuruan Fakultas Teknik Unveristas Negeri Makassar, 1-25.

Yusuf, S. (2017). Bimbingan dan Konseling Perkembangan Suatu Pendekatan Komprehensif. Bandung: Refika Aditama.

Zarirah, Intan, M. R., \& Herdi. (2017). Kompetensi Teknologi Guru BK. Insight: Jurnal Bimbingan dan Konseling, 3(1), 153-159. 